USGS-OFR-94-413-A

U.S. Department of the Interior

U.S. Geological Survey

\title{
Gravity and magnetic data across the Ghost Dance Fault in WT-2 Wash, Yucca Mountain, Nevada
}

by

H.W. Oliver and R.F. Sikora

94-43-A, Geophysical Documentation

\section{Open-File Report 94-413-A}

Prepared in cooperation with the Nevada Field Office

U.S. Departmem of Energy

(Anteragency Agreemem DE-A108-92NV10874)

This report is prelininary and has not been reviewed for conformity with U.S. Geological Survey editorial standards or with the North American Stratigraphic Code. Any use of trade, firm, or product names is for descriptive purposes only and does not imply endorsement by thic U.S. Government.

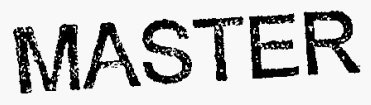

Menlo Park, California

1994

DISTRIBUTION OF THIS DOCUMENT IS UNLLMITED 


\section{DISCLAIMER}

This report was prepared as an account of work sponsored by an agency of the United States Government. Neither the United States Government nor any agency thereof, nor any of their employees, makes any warranty, express or implied, or assumes any legal liability or responsibility for the accuracy, completeness, or usefulness of any information, apparatus, product, or process disclosed, or represents that its use would not infringe privately owned rights. Reference herein to any specific commercial product, process, or service by trade name, trademark, manufacturer, or otherwise does not necessarily constitute or imply its endorsement, recommendation, or favoring by the United States Government or any agency thereof. The views and opinions of authors expressed herein do not necessarily state or reflect those of the United States Government or any agency thereof. 


\section{U.S. DEPARTMENT OF THE INTERIOR \\ BRUCE BABBITT, Secretary}

U.S. GEOLOGICAL SURVEY

Gordon P. Eaton, Director

The use of trade, product, industry, or firm names is for descriptive purposes only and does not imply endorsement by the U.S. Government.

For additional information write to:

Chief, Geologic Studies Program

Yucca Mountain Project Branch

U.S. Geological Survey

Box 25046, MS 421

Denver Federal Center

Denver, CO 80225
Copies of this report can be purchased from:

U.S. Geological Survey

Earth Science Information Center

Open-File Reports Section

Box 25286, MS 517

Denver Federal Center

Denver, CO 80225 


\section{Table of Contents}

$\begin{array}{lr}\text { Abstract } & \text { Page } \\ \text { Introduction } & 1 \\ \text { Acknowledgments } & 2 \\ \text { General geology and drill holes } & 2 \\ \text { Gravity data } & 4 \\ \text { Density data } & 5 \\ \text { Magnetic data } & 8 \\ \text { Preliminary results } & 10 \\ \text { Conclusions and recommendations } & 10 \\ \text { Description of diskette } & 15 \\ \text { References } & 17 \\ \end{array}$

Tables

1. Principal facts for gravity stations along 6 profiles A-A' (fig. 2)

2. Magnetic measurements along profile $A-A^{\prime}$

\section{Illustrations}

Figure 1. Index map showing new gravity and ground magnetic profile $A-A^{\prime}$ and its location relative to the potential repository at Yucca Mountain

Figure 2. Topographic index map showing location of profile $A-A^{\prime}$ and all gravity stations 2 4

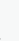




\section{Units, Conversion Factors, and Vertical Datum}

All elevation and distance measurements in this report are in feet (ft) or miles (mi), because that is the unit used by the LBL surveyors.

Multiply

feet (ft)

mile $(\mathrm{m})$

square mile $\left(\mathrm{mi}^{2}\right)$
By

0.3048

1.609

2.590
To obtain

meter (m)

kilometer $(\mathrm{km})$

square kilometer $\left(\mathrm{km}^{2}\right)$

Sea level: In this report "sea level" refers to the National Geodetic Vertical Datum of 1929 (NOVD of 1929)-a geodetic datum derived from a general adjustment of the firstorder level nets of both the United States and Canada, formerly called Sea Level Datum of 1929.

Gravity measurements are in milligals (mGal)

$$
\begin{aligned}
1 \mathrm{mGal} & =10^{-3} \mathrm{~cm} / \mathrm{sec}^{2} \text { (acceleration) } \\
& =10^{-3} \mathrm{dyne} / \mathrm{gram} \text { mass (force) }
\end{aligned}
$$

Magnetic measurements are in nanoteslas (nT)

$$
1 \mathrm{nT}=1 \gamma(\text { gamma })=10^{-5} \text { gauss }
$$

Remanent magnetization measurements are in amperes per meter $\left(\mathrm{Am}^{-1}\right)$

$$
1 \mathrm{Am}^{-1}=10^{-3} \mathrm{emu} / \mathrm{cm}^{3}
$$

For additional information on conversion factors between English (fps), metric (cgs), and the International System (SI) units, see U.S. National Bureau of Standards (1977). 


\begin{abstract}
Detailed gravity and ground magnetic data were obtained in September 1993 along a 4650 $\mathrm{ft}$-long profile across the Ghost Dance Fault system in WT-2 Wash. Gravity stations were established every 150 feet along the profile. Total-field magnetic measurements made initially every $50 \mathrm{ft}$ along the profile, then remade every $20 \mathrm{ft}$ through the fault zone. These new data are part of a geologic and geophysical study of the Ghost Dance Fault (GDF) which includes detailed geologic mapping, seismic reflection, and some drilling including geologic and geophysical logging. The Ghost Dance Fault is the only throughgoing fault that has been identified within the potential repository for high-level radioactive waste at Yucca Mountain, Nevada.
\end{abstract}

Preliminary gravity results show a distinct decrease of 0.1 to $0.2 \mathrm{mGal}$ over a 600 -ft-wide zone to the east of and including the mapped fault. The gravity decrease probably marks a zone of brecciation. Another fault-offset located about $2000 \mathrm{ft}$ to the east of the GDF was detected by seismic reflection data and is also marked by a distinct gravity low.

The ground magnetic data show a 200 -ft-wide magnetic low of about $400 \mathrm{nT}$ centered about $100 \mathrm{ft}$ east of the Ghost Dance Fault. The magnetic low probably marks a zone of brecciation within the normally polarized Topopah Spring Tuff, the top of which is about $170 \mathrm{ft}$ below the surface, and which is known from drilling to extend to a depth of about $1700 \mathrm{ft}$. Three-component magnetometer logging in drill hole WT-2 located about 2700 $\mathrm{ft}$ east of the Ghost Dance Fault shows that the Topopah Spring Tuff is strongly polarized magnetically in this area, so that fault brecciation of a vertical zone within the Tuff could provide an average negative magnetic contrast of the $4 \mathrm{Am}^{-1}$ needed to produce the 400 nT low observed at the surface. 
Additional magnetic data and limited gravity data are needed to determine the north-south extent of the geophysical anomalies and to better define the rather striking anomalies discovered in this initial survey.

\section{Introduction}

A gravity and magnetic investigation of the Ghost Dance Fault was begun as part of an effort to help geologically characterize Yucca Mountain as a potential site for the storage of commercial spent nuclear fuel and high-level radioactive waste. The Ghost Dance Fault is considered one of the more important structural features, as it is the only through-going fault that has been identified within the proposed repository area (Spengler and others, 1993; see fig. 1, this report). Seismic reflection, vertical seismic profiling (VSP), and cross-hole seismic profiling data are also being obtained across the Ghost Dance Fault by the Lawrence Berkeley Laboratory (LBL) in conjunction with this study (Majer and Karageorgi, 1994).

\section{Acknowledgments}

Dr. Cameron Ainsworth assisted with the staking and both the gravity and ground magnetic field measurements in September 1993. E.L. Majer and his coworkers at LBL surveyed in all of our gravity stations, and they used them also for their seismic control. Elaine Ezra of EG \& G, Las Vegas, compiled a new 1:6,000-scale topographic map of the immediate area of WT-2 Wash (EG\&G, 1993) which proved invaluable for plotting our data points and making inner-zone terrain corrections to our gravity data. 

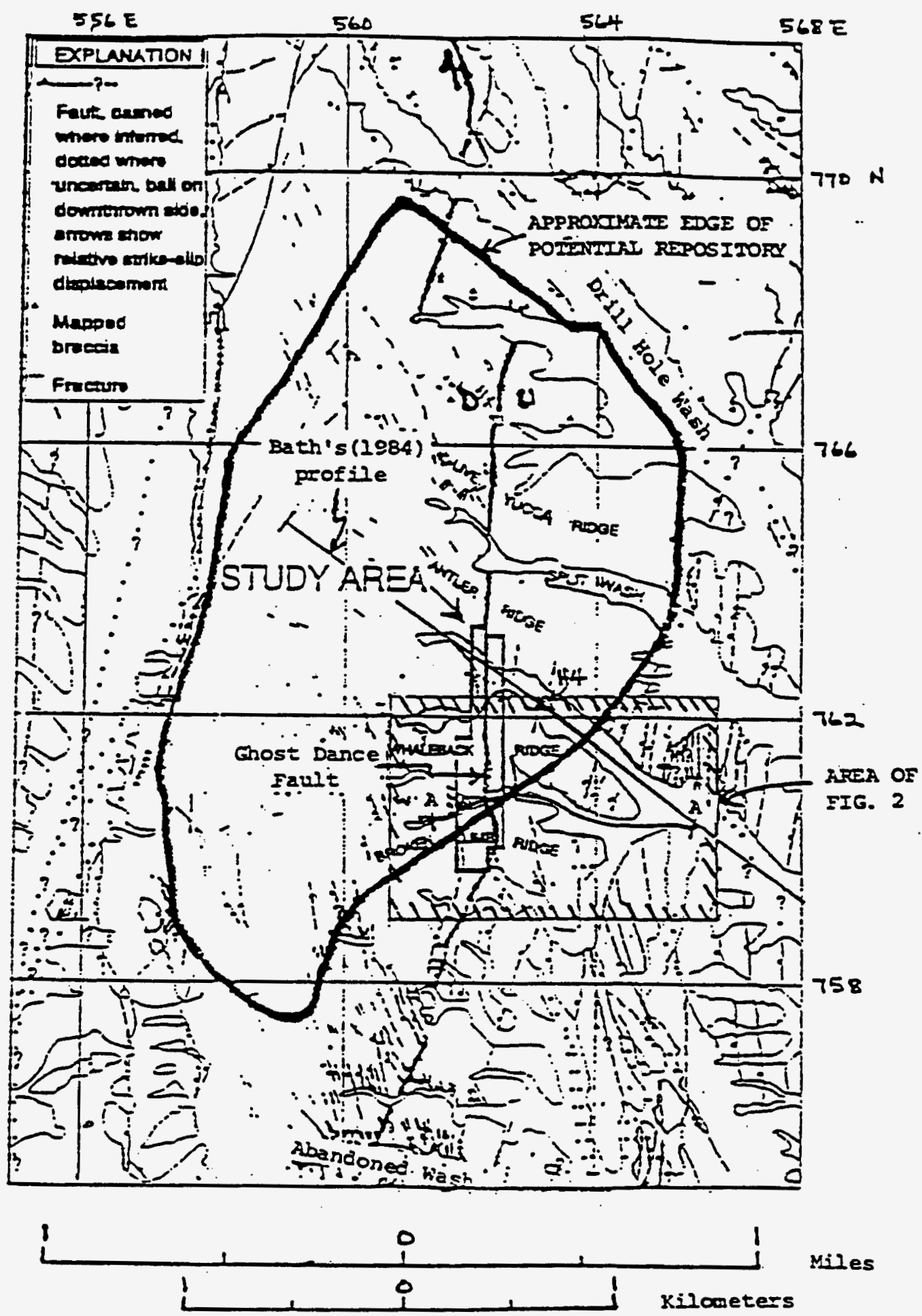

Figure 1. Inciex map showing new gravity and ground magnetic prosile h-h' and its location relarive to the potentizl repository, the Ghost Dance Fault, and geolocic "study area" and Bath's(1984) cround magnetic profile through "us wash"north of Whale Back Ricge. Reference lires are Nevacia $s$ ite coozainates in thousancs oi feet. After Spengler anc others(1903,fig.1). Scale 1:27,600. 


\section{General Geology and Drill Holes}

Miocene volcanic tuffs make up the geologic section in the potential repository area and their stratigraphy and nomenclature has been recently revised by Sawyer and others (in press). The Tiva Canyon Tuff crops out over most of the area and has an age of $12.7 \mathrm{Ma}$

(Hudson and others, 1994, table 1). This tuff is underlain by the two thin units (generally less than $100 \mathrm{ft}$ thick) known as the Yucca Mountain and Pah Canyon Tuffs, and these tuffs are underlain by the $12.8 \mathrm{Ma}$ Topopah Spring Tuff. Within the WT-2 Wash area, drilling in WT-2, UZ-7, and WT-2, and geologic mapping have established that the thickness of the Tiva Canyon Tuff there ranges from about $160 \mathrm{ft}$ at UZ-7 to $260 \mathrm{ft}$ at WT-2. The Tiva Canyon Tuff is underlain by only 10 to $20 \mathrm{ft}$ of Yucca Mountain and Pah Canyon Tuffs. The Topopah Spring Tuff was found to be about $1000 \mathrm{ft}$ thick in well WT2 (R.W. Spengler, personal commun., 1994). The top of the Topopah Spring Tuff is a very important boundary magnetically, because it represents the bottom of reversely polarized volcanic strata in the WT-2 Wash area.

Structurally, Yucca Mountain consists of a series of north-trending, east-tilted, 0.6- to 2.5-mi wide structural blocks bounded by north-trending westward-dipping, high-angle faults (U.S. Geological Survey, 1984). The Ghost Dance Fault is one of these northtrending faults (fig. 1) and is thought to displace volcanic strata by about $100 \mathrm{ft}$ in the WT-2 Wash area. Detailed mapping by Spengler and others (1993) indicates that the Ghost Dance Fault is not a single fault but "represents the major fault within a previously unrecognized zone of minor faults, fractured rock, and stratal flexing that extends over a width of at least $700 \mathrm{ft} . "$ 


\section{Gravity Data}

Gravity data (table 1) were collected at stations spaced $150 \mathrm{ft}$ apart along profile A-A' across the Ghost Dance Fault (fig. 2) using LaCoste and Romberg gravity meter G17C. Gravity-meter performance and calibration factors were checked in March 1993 over the Mt. Hamilton gravity meter calibration loop in California (Barnes and others, 1969), and its performance qualifies under USGS Technical Procedure GPP-01, Rev. 2, Gravity Methods (1991). Gravity data were reduced using the Geodetic Reference System of 1967 (International Union of Geodesy and Geophysics, 1971) and referenced to the International Gravity Standardization Net 1971 gravity datum (Morelli, 1974, p. 18) via base station MERC at the USGS core library building at Mercury, Nevada (Ponce and Oliver, 1981, p. 13). Because of recent building construction near base station MERC, the gravity value there now has a new value of $979,518.91 \mathrm{mGal}$, determined by repeated ties to nearby station TCCA, which is located on basement rocks (D.A. Ponce, written commun., 1993).

Gravity stations were surveyed using an electronic-distance-measurement instrument, and station elevations are accurate to within about $0.1 \mathrm{ft}$ relative to a reference bench mark. Terrain corrections were computed to a radial distance of $104 \mathrm{mi}$ and involved a 3-part process: (1) Hayford-Bowie zones A and B with an outer radius of $223 \mathrm{ft}$ were estimated in the field with the aid of tables and charts, or sketched and later calculated in the office, (2) Hayford-Bowie zones C and D with an outer radius of $1935 \mathrm{ft}$ were calculated by averaging compartment elevations on a circular template based on Hayford's system of zones (Swick, 1942, p. 66), and (3) terrain corrections from a distance of $0.37 \mathrm{mi}$ to 104 mi were calculated using a digital elevation model and a procedure by Plouff (1977). Small amplitude errors in some of the profiles may be related to small errors in the terrain 
Tabla 1. pelncipal cacto lor gravlty otations along proflia $\lambda-\lambda^{\prime}$ (flg. 2 ). The dlstances between successlue stations are all 150 ft. Abbreviated heading aro as lollows: "TC A-D 2.67" shows a otatlon llsting of Inner zone terraln correctlons Lor llaylord zonns A-D corresponding to an assumed texraln denslty of $2.67 \mathrm{~g} / \mathrm{cm}$; "Total TC 2.67\% relers to the total terraln correctlon Cor llaycord rones $\mathrm{A}-0$ extending to a distance of $103.6 \mathrm{~km}$ from each

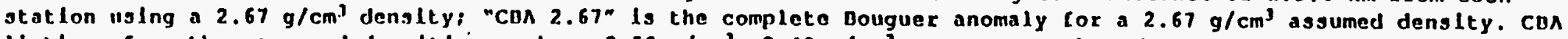
listings tor other assumed densitles such as $2.50 \mathrm{~g} / \mathrm{cm}^{3}, 2.10 \mathrm{~g} / \mathrm{cm}^{3}$, etc., are also shown.

\begin{tabular}{|c|c|c|c|c|c|c|c|c|c|c|c|c|c|c|c|c|c|}
\hline \multirow[t]{2}{*}{$\begin{array}{c}\text { station } \\
\text { No. }\end{array}$} & \multicolumn{2}{|c|}{ n lout ltude } & \multicolumn{2}{|c|}{ Longltude } & \multirow{2}{*}{$\begin{array}{l}\text { vie- } \\
\text { vation } \\
\text { (ft) }\end{array}$} & \multirow{2}{*}{$\begin{array}{l}\text { Observed } \\
\text { gravlty } \\
\text { (mGal) }\end{array}$} & \multirow{2}{*}{$\begin{array}{l}\text { Eree } \\
\text { Alr } \\
\text { Anomaly } \\
\text { (mGal) }\end{array}$} & \multirow{2}{*}{$\begin{array}{l}\text { Slmple } \\
\text { Bouguer } \\
\text { Anomaly } \\
2.67 \\
\text { mGal }\end{array}$} & \multirow{2}{*}{$\begin{array}{l}T C \\
A-D \\
2.67 \\
(m G a)\end{array}$} & \multicolumn{2}{|c|}{$\begin{array}{l}\text { Total CBn } \\
\text { TC }\end{array}$} & $\operatorname{con}$ & CBA & CBA & CBN & CBA & \multirow{2}{*}{$\begin{array}{c}\text { CBA } \\
1.60 \\
(\operatorname{mga} 1)\end{array}$} \\
\hline & IDeg & $g(n)$ & loeg & $(M \mid n)$ & & & & & & $\operatorname{lmg}$ & $\begin{array}{c}2.67 \\
\text { l) }(\mathrm{mGa})\end{array}$ & $\begin{array}{c}2.50 \\
(\mathrm{mGa} 1)\end{array}$ & $\begin{array}{c}2.40 \\
(\mathrm{mGa})\end{array}$ & $\begin{array}{c}2.20 \\
(\mathrm{mgal})\end{array}$ & $\begin{array}{c}2.00 \\
(\mathrm{mGa})\end{array}$ & $\begin{array}{c}1.00 \\
(\operatorname{mga} 1)\end{array}$ & \\
\hline & 36 & & 6 & & & & & & & & & & & & & 18 & \\
\hline & 6 & & & & & & & & & & & & & & & & \\
\hline & 6 & & & & & & & & 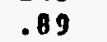 & & $\overline{7}$ & 92 & 8 & 60 & -1 & & \\
\hline & 6 & & 16 & & & & & & 97 & & & -1 & & & -1 & 95 & 13 \\
\hline & 6 & & 16 & & & & & -1 & 8 & & 30 & -1 & 8 & & -1 & & -1 \\
\hline & 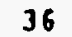 & & 16 & & & & & & & & & & & & -1 & & \\
\hline & & & & & & & & & & & & & & & & & \\
\hline & & & & & & & & & & & & & & & -1 & & \\
\hline & & & 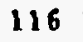 & & & & & - & • & & & & & & -1 & & \\
\hline & 36 & & te & & & & & & & & & - & -1 & & -1 & 10 & \\
\hline & 36 & & 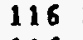 & & & & & - & . & & -1 & 7 & -1 & - & -1 & os & -1 \\
\hline & 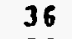 & & S & & 6 & & & & .1 & 1 & & & & - & -1 & & 10 \\
\hline & & & te & & & & & & & & & & & & & & \\
\hline & & & t & & & & & & & & & & & & & 62 & 12 \\
\hline & & & the & & & & & & . & & -1 & -1 & -1 & & & 54 & \\
\hline & 36 & & 1 & & & & & -1 & .7 & . & & & & & & 50 & 03 \\
\hline & 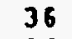 & & 11 & & 3 & & & & .8 & & & & & & & & \\
\hline & & & 1 & & & & & & & & & & & & & & \\
\hline & & & 1 & & 8 & & & -1 &. & . & & & & & & 19 & \\
\hline & 36 & & 1 & & & & & & & & & & & & & & 13 \\
\hline & & & 11 & & .5 & & & -1 & & & & -1 & -1 & & -1 & 03 & 68 \\
\hline & 36 & & 116 & & .5 & & 9 & -1 & .3 & 60 & & 09 & & & -1 & 91 & 62 \\
\hline & 36 & & 116 & & .0 & & & & .3 & & & & & & -1 & 09 & 19 \\
\hline & 36 & & 116 & & & & & & & & & & & & & & \\
\hline & 36 & & 116 & & & & & & .2 & & & & & & & & 13 \\
\hline & 36 & & 116 & & & & & & & & & & & & & 96 & .72 \\
\hline & 36 & & 116 & & .05 & & & & .1 & & & & & & & 88 & 67 \\
\hline & 36 & & 116 & 26 & 3988.6 & 97 & -2 & -15 & .2 & 1.39 & -1 & -117.39 & -112.30 & 2.12 & -121.94 & .76 & .58 \\
\hline & 36 & & 116 & 26. & 3979.8 & & & & .1 & 1.35 & & -117.24 & -112.16 & & & .68 & .52 \\
\hline & 36 & & 116 & & 3972.1 & & & & & & & & & & & & \\
\hline 160 & & & 116 & .56 & 3964.5 & 979196.51 & -20.72 & -155.93 & & 20 & 5.90 & -117.30 & -142 & 2. & -121.98 & -111.85 & -101.7 \\
\hline
\end{tabular}




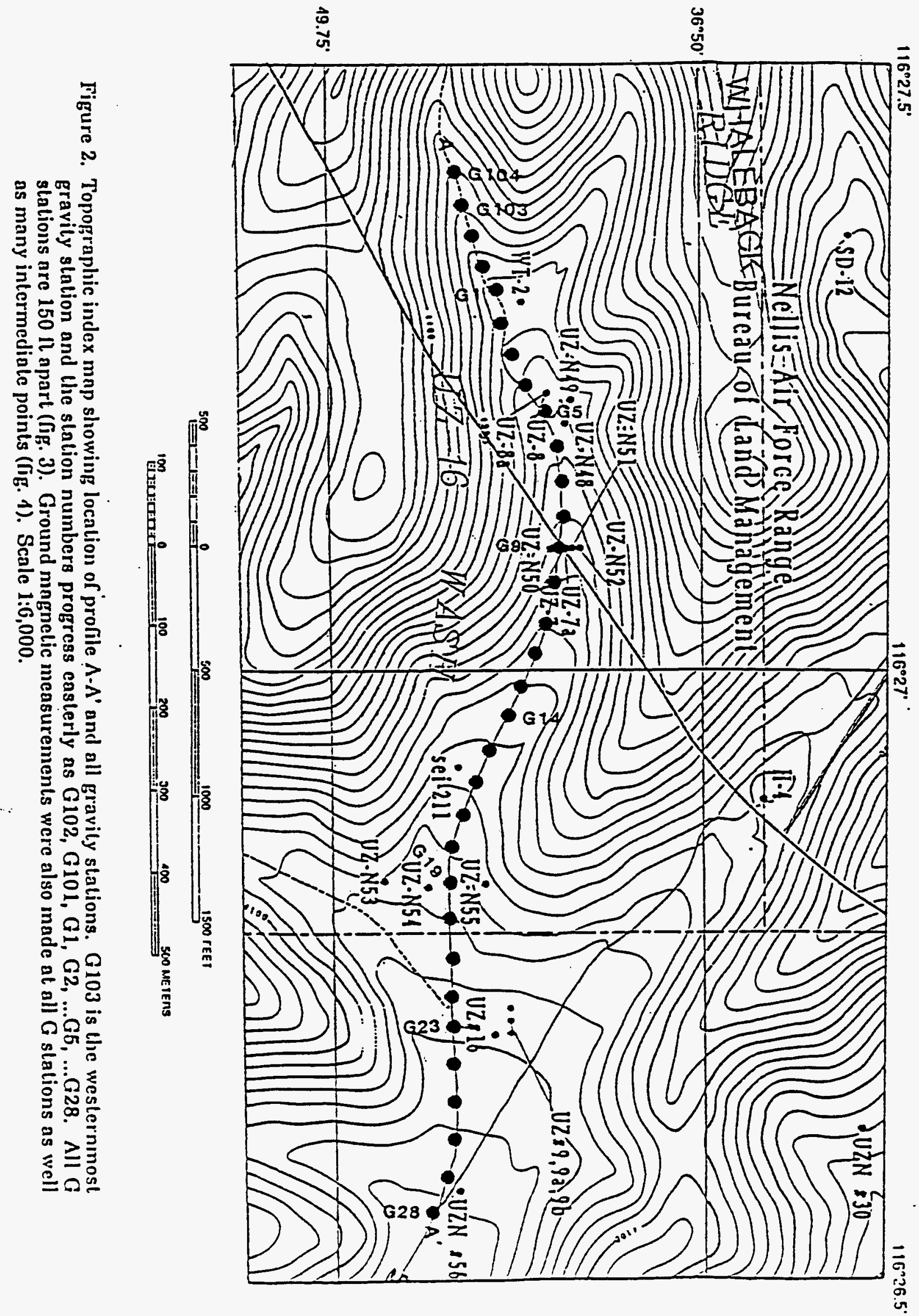


corrections, particularly where profiles cross topographic features such as hills. Gravity data were reduced to complete Bouguer anomalies using reduction densities of $1.6,1.8$, 2.0. 2.2, 2.4, and $2.67 \mathrm{~g} / \mathrm{cm}^{3}$, and include earth-tide, instrument drift, free-air, Bouguer, latitude, curvature, and terrain corrections.

In general, the observed gravity data are accurate to about $0.03 \mathrm{mGal}$, and the Bouguer anomalies are accurate to about $0.1 \mathrm{mGal}$. Principal facts of the gravity data are listed (table 1), and the data are plotted along profile $\mathrm{A}-\mathrm{A}^{\prime}$ (figure 3 ). The smoothness of the profiled data, particularly in the interval between G10 and G19, suggests that the relative accuracy of the Bouguer anomalies in this area may be good to $\pm 0.05 \mathrm{mGal}$, although the single-station gravity high at station G102 may indicate that Bouguer anomalies at this station could be too high by about $0.15 \mathrm{mGal}$. The terrain correction for zones A-D for this station is the largest of all stations $(1.23 \mathrm{mGal})$, and large terrain corrections cause greater uncertainties, perhaps as much as $0.2 \mathrm{mGal}$ in this case.

\section{Density Data}

No new density data were obtained from the WT-2 Wash area. However, Snyder and Carr $\left(1984\right.$, table 1) report an average value of $2.1 \mathrm{~g} / \mathrm{cm}^{3}$ for the density of the Tiva Canyon Tuff; this tuff forms most of the topography in the study area. Study of the variations in Bouguer anomalies (fig. 3) suggests that a reduction density of $2.0 \mathrm{~g} / \mathrm{cm}^{3}$ provides the flattest curve over the western third of the profile (between G103 to G10); the $2.0 \mathrm{~g} / \mathrm{cm}^{3}$ curve in this interval is therefore independent of the eastward drop-off in elevation shown on the elevation profile. The eastern two-thirds of the profile (G11-G12) shows an eastward increase in gravity for all densities, and this regional gravity rise is 


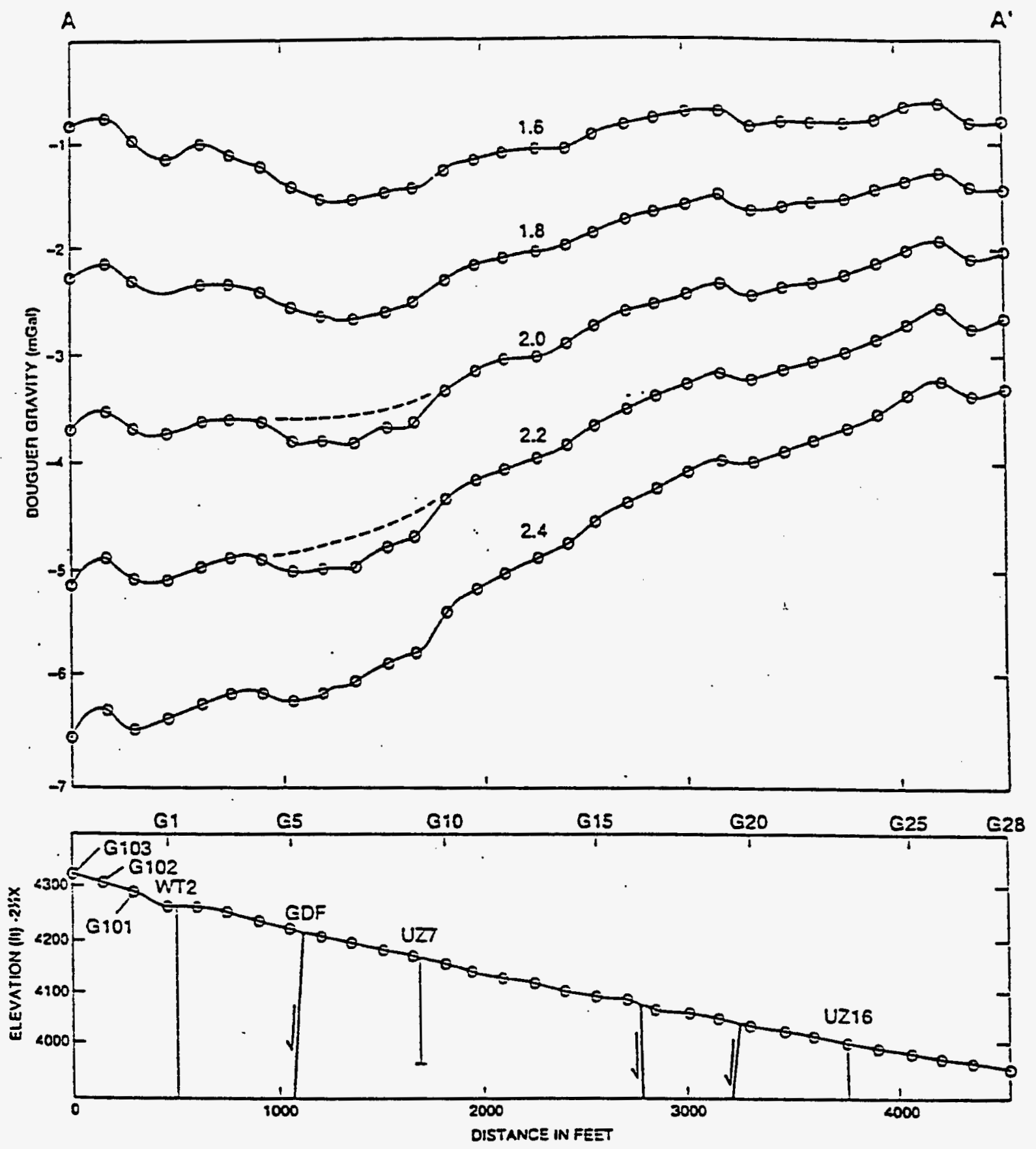

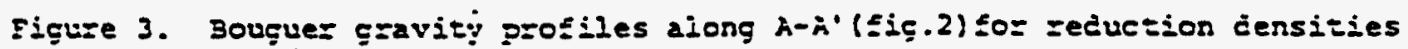
1.6.j.8.2.0.2.2,and $2.4 \mathrm{~g} / \mathrm{cm}$. The elevazion $0=0$ file shows the locasion of the Ghost Dance $52 u 2=(G D F)$. Wwo othez faul=s near Gl6 anc 60 based on seismis =eflection studies (majez and

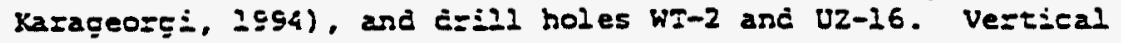
exaggezation of the elevacion protile is 2.5 . 
known to be caused by an eastward rise in Paleozoic basement rocks in precisely this area (Oliver and Fox, 1993; Oliver and Ponce, in press; Oliver and Mooney, 1992).

\section{Magnetic Data}

Ground magnetic data were obtained along profile A-A' (table 2, fig. 4). A Geometrics portable proton precession magnetometer model G-816 was used to collect data with the sensor $8 \mathrm{ft}$ above the surface. The whole $4650 \mathrm{ft}$-long profile was initially measured at 50 $\mathrm{ft}$ intervals, and later repeated between G4 and G8 across the Ghost Dance Fault with a reduced spacing of about $20 \mathrm{ft}$.

A three-component magnetometer log of drill hole WT-2 was made to a depth of about $1640 \mathrm{ft}$ by P.H. Nelson (written commun., 1994). These new data confirm that magnetically reversely polarized strata extend from the surface to a depth of $230 \mathrm{ft}$, below which the strata (the Topopah Spring Tuff) are normally magnetized to a depth of about $1700 \mathrm{ft}$. For perspective, the magnetic stratigraphy at Yucca Mountain is summarized by Oliver and others (1990, Table 2.2-2).

For a regional perspective of the magnetic field within and surrounding the potential repository, see Oliver and others (1991, fig. 3) and Kirchoff-Stein and others (1989).

\section{Preliminary Results}

The gravity data plots do not indicate any striking anomalies along $\mathrm{A}-\mathrm{A}^{\prime}$, but a distinct decrease of about $0.2 \mathrm{mGal}$ at $\mathrm{G} 5$ corresponds with the mapped location of the Ghost Dance Fault. Relative to the regional trend shown as dashed lines on the 2.0 and 2.2 
aable 2. Mgnetic peasurements along prosile $\lambda-\lambda^{\prime}$. Elevations of the macnetic stajions are 8 ft hichez than the costesponding gravity stations (Table i) because the magnetic sensor is at the top of an 6 st pole. Elevarions of intermediace magnesic measurements vere linearly interpolated between the surveyed stations 6104, 6203, G102, etc. and are prefixed by an $x$.

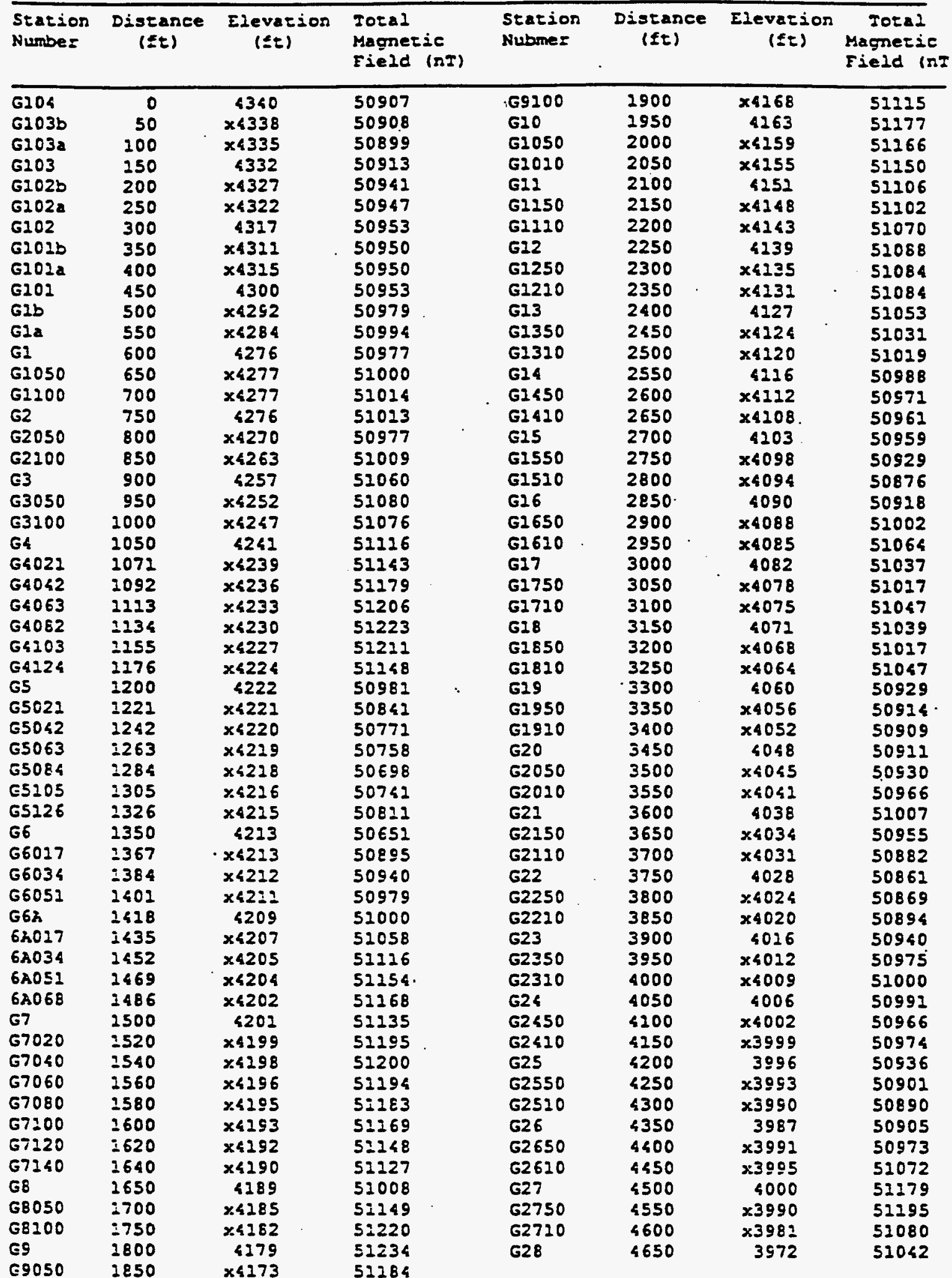




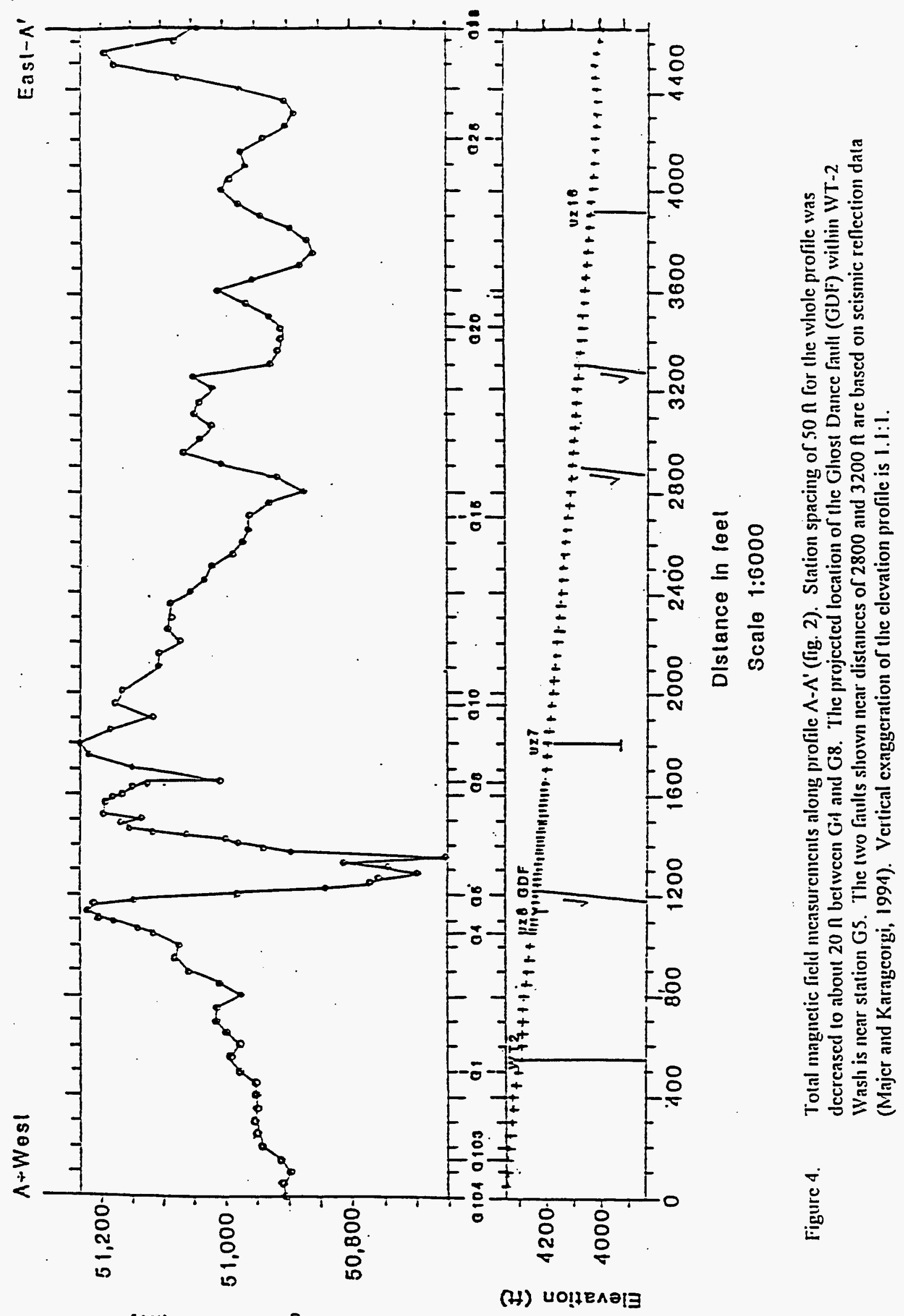

(1U) D|ə!! ग!มวuธEผ 
$\mathrm{g} / \mathrm{cm}^{3}$ curves (fig. 3), the $0.2-\mathrm{mGal}$ decrease seems to extend from $\mathrm{G} 5$ to $\mathrm{G} 9$ and may mark a zone about $600 \mathrm{ft}$ wide of relatively low-density fault breccia. Similarly, another fault with a vertical displacement of about $70 \mathrm{ft}$ near G20 (Majer and Karageorgi, 1994) is also marked by a $0.15-\mathrm{mG}$ al local gravity low. However, a similar fault near $\mathrm{Gl} 6$ does not have a corresponding gravity low or offset.

By contrast, the ground magnetic data plot (fig. 4) shows striking anomalies associated not only with the Ghost Dance Fault but with the other two faults as well. The Ghost Dance Fault anomaly consists of a magnetic low of nearly $400 \mathrm{nT}$ centered only $20 \mathrm{ft}$ east of the projected fault location, with broader magnetic highs of about $200 \mathrm{nT}$ both east and west of the low. The magnetic low is about $200 \mathrm{ft}$ wide, implying an approximate $200 \mathrm{ft}$ wide source zone at the fault. The high to the west is somewhat questionable because the survey line passed about $80 \mathrm{ft}$ south of drill hole UZ-8, which contains a 35-ft deep, 8-indiameter metal casing. We did not know about this cased hole at the time of our measurements and need to run a N-S profile through UZ-8 to determine the lateral extent of its magnetic effect. However, cased holes typically have only a magnetic high or magnetic low signature and are not bipolar (Frischknecht and others, 1985). Hence, the 400-nT magnetic low at the Ghost Dance fault is not an artifact of the UZ-8 casing but a significant finding and agrees with Bath and Jahren's (1984, fig. 21) finding of a similar magnetic low associated with the Ghost Dance Fault in a truck-mounted-magnetometer profile in the next canyon to the north (fig. 1). Modeling of these magnetic lows is complicated by the fact that the approximate upper $200 \mathrm{ft}$ of earth materials along the whole profile are composed of the reversely polarized Tiva Canyon Tuff with very strong, reversed-polarity, remanent magnetizations in the range of 1 to $6 \mathrm{Am}^{-1}$ in the lower part of the formation (Rosenbaum and Snyder, 1985). 
The presence of magnetic rocks in the valley walls above profile $A-A^{\prime}$ makes the interpretation and modeling of the magnetic profile more difficult (Rasmussen and Pedersen, 1979). However, a comparison of the magnetic anomaly locations (fig. 4) with the proximity to side walls of WT-2 Wash (fig. 2) shows that the local anomalies are virtually independent of this possible problem. For example, the approximately $300-n T$ eastward rise in the magnetic field between G26 and G27 (fig. 4) occurs in a nearly flat portion of the wash where the sidewalls are gentle (less than $10^{\circ}$ ) and start rising about $500 \mathrm{ft}(150 \mathrm{~m})$ to the north and south of the profile. Thus, this magnetic anomaly must reflect subsurface magnetic structure. A more general westward increase in the magnetic field strength from about $50,950 \mathrm{nT}$ near $\mathrm{G} 14$ to about $51,200 \mathrm{nT}$ near $\mathrm{G}$ (fig. 4) does correlate with a narrowing of WT-2 Wash (fig. 2). However, further narrowing of this wash west of WT-2 does not produce a magnetic rise. Certainly, the sharp magnetic low of over $400 \mathrm{nT}$ near the Ghost Dance Fault is not significantly affected by proximity to the valley walls of WT-2 Wash.

Some modeling of possible sources of the $400 \mathrm{nT}$ magnetic low has been carried out, but nothing tried so far is completely satisfactory. The most promising model is a $200-\mathrm{ft}$-wide tabular body which may represent a loss of magnetic remanence within the fault zone that penetrates the normally polarized Topopah Spring Tuff. By assuming an average value of magnetization of $4 \mathrm{Am}^{-1}$ for the Topopah Spring Tuff, the magnetic low can be fit rather well. However, brecciation of the upper 160 to $200 \mathrm{ft}$ of Tiva Canyon Tuff would produce a sharper high superimposed on the modeled low, and a significant magnetic high is not observed. There is a sharp 100-nT blip located about $100 \mathrm{ft}$ east of G5 within the 400-nT low that perhaps could be modeled if additional detailed magnetic data became available. Such modeling might show the nature and extent of brecciation associated with the Ghost Dance Fault within the Tiva Canyon Tuff. 
Another possible source for the magnetic low associated with the Ghost Dance Fault is a tabular body within the fault zone with a greater reversed polarization than the Tiva Canyon Tuff. A dike-like model with a contrast of $4 \mathrm{Am}^{-1}$ has been tested (Oliver and others, 1993), but there is no geologic evidence for such a body at present. The top of the modeled body is about $30 \mathrm{ft}$ below the surface.

\section{Conclusions and Recommendations}

Ground magnetic measurements combined with limited gravity data offer considerable promise for inexpensively tracing the Ghost Dance Fault under alluvial cover and determining the lateral extent of faulting within the system.

To further facilitate this work, two short magnetic lines should be run at right angles across all of the drill holes within $200 \mathrm{ft}$ of $\mathrm{A}-\mathrm{A}^{\prime}$ that are known to have steel casing to determine possible effects on the magnetic profile (fig. 4). The most important such well is UZ-8, only $80 \mathrm{ft}$ to the north of the profile at G4082, where the highest magnetic measurement of $51223 \mathrm{nT}$ was measured (table 2). Other such wells include WT-2, UZN48, UZ-7, UZ-N50, and UZ-N56. Information on the depth, size, and type of casing needs to be compiled for all these wells. We also recommend obtaining density and magnetic logs for these wells as well as making systematic magnetic susceptibility and remanent magnetization measurements of core samples. A magnetic log is available for UZ-16 (P.H. Nelson, written commun., 1994) which would be very helpful to this study.

Additional ground magnetic measurements are recommended for the following areas: (1) west of A along WT-2 Wash so as to extend the current survey about $1000 \mathrm{ft}$ to the west 
and make it coincide exactly with the seismic reflection survey (Majer and Karageorgi, 1994); (2) across the Ghost Dance Fault (GDF) in "H4 Wash" to the north of Whale Back Ridge to check out the GDF magnetic signature reported by Bath and Jahren (1984); and (3) along Whale Back Ridge where the magnetic effect of the GDF will be free from possible sidewall effects. About five detailed ground magnetic profiles spaced about $20 \mathrm{ft}$ apart should also be obtained both to the north and south of that portion of $A-A^{\prime}$ between G3 and G10 to test the N-S continuity of the $400 \mathrm{nT}$ magnetic low associated with the Ghost Dance Fault measured along A-A' (fig. 4). Someone should also look at the canyon walls, making simple fluxgate polarity checks to see where the profile is relative to magnetic stratigraphy.

Because of the possibility of a reversely polarized tabular body within the GDF zone, detailed geologic inspection of the zone and shallow drilling of the magnetic low might provide important information to help characterize the area. Ground magnetic surveys should also be run across any other faults within Yucca Mountain that are known to contain tabular intrusive bodies such as the basaltic dike in the Solitario Canyon Fault (U.S. Geological Survey, 1984, p. 29).

It would also be helpful to obtain ground magnetic data across the southern extension of the Ghost Dance fault in Abandoned Wash (fig. 1). In this area, the Tiva Canyon Tuff has been eroded and the normally polarized Topopah Spring Tuff is exposed at the surface. Thus, the fault breccia model should produce a simple magnetic low in this area, uncontaminated by any reversely polarizing effects.

Electrical studies in the area of Drill Hole Wash (fig. 1) by Hoover (1982), Smith and Ross (1982), and D.P. Klein and Emie Hardin (written commun., 1994) suggest that some 
fault zones at Yucca Mountain have a lower resistivity because of percolation of water through the opening. Also, the long-term effect of percolation has caused alteration of at least some fault zones and has produced a lower resistivity within the zone. Thus, resistivity and induced polarization measurements should also be considered for further studies of the Ghost Dance Fault zone.

\section{Description of diskette}

The data described in this report (tables 1 and 2) are available on 3 1/2-in, high-density, double-sided diskette formatted for Macintosh computer using Microsoft Word. The diskette requires a Macintosh computer/word processor and contains a total of three files:

readme.txt, a description of the gravity and magnetic data; yw.cba, principal facts of gravity data along profile A-A'; ya.mag, ground magnetic data along profile $\mathrm{A}-\mathrm{A}^{\prime}$

\section{References}

Bath, G.D., and Jahren, C.E., 1984, Interpretations of magnetic anomalies at a potential repository site located in the Yucca Mountain area, Nevada Test Site: U.S. Geological Survey Open-File Report 84-120, 40 p. +4 plates.

EG \& G, 1993, Yucca Mountain repository topographic base map, sheet B: EG \& G Map, Yucca Mountain Project 93-203.2, scale 1:6,000. 
Frischknecht, F.C., Grette, R., Raab, P.V., and Meredith, J., 1985, Location of abandoned wells by magnetic surveys: Acquisition and interpretation of aeromagnetic data for five test areas: U.S. Geological Survey Open-File Report 85-614A, 64 p.

Hoover, D.B., Chomack, M.P., and Broker, M.M., 1982, E-Field ratio telluric traverses near Fortymile Wash, Nevada Test Site, Nevada: U.S. Geological Survey Open-File Report 82-1042, 14 p.

Hudson, M.R., Sawyer, D.A., and Warren, R.G., 1994, Paleomagnetism and rotation constraints for the middle Miocene southwestern Nevada volcanic field: Tectonics, v. 13, no. 2, p. 258-274.

International Union of Geodesy and Geophysics, 1971, Geodetic Reference System 1967: International Association of Geodesy Special Publication No. 3, $116 \mathrm{p}$.

Kirchoff-Stein, K.S., Ponce, D.A., and Chuchel, B.A., 1989, Preliminary aeromagnetic map of the Nevada Test Site and vicinity: U.S. Geological Survey Open-File Report 89446, scale 1:100,000.

Majer, E.L., and Karageorgi, Eleni, 1994, Ghost Dance surface reflection profiles: DOEYMSCO, YMP-USGS Rock Characteristics-/Lawrence Berkeley Laboratory Milestone Report 3GGF240M, 16 p.

Morelli, C., (Ed.), 1974, The International Gravity Standardization Net, 1971: International Association of Geodesy Special Publication No. 4, 194 p. 
Oliver, H.W., and Fox, K.F., 1993, Structure of Crater Flat and Yucca Mountain, southeastern Nevada, as inferred from gravity data: American Nuclear Society Proceedings of the Fourth Annual International Conference on High Level Waste Management, v. 2, p. 1812-1817.

Oliver, H.W., Hardin, E.L., and Nelson, P.H., eds., 1990, Status of data, major results, and plans for geophysical activities, Yucca Mountain Project: U.S. Department of Energy Report YMP/90-38, 236 p.

Oliver, H.W., Majer, E.L., and Spengler, R.W., 1994, Geophysical investigations of the Ghost Dance fault, Yucca Mountain, Nevada (Abs): Geological Society of America Cordilleran Section Meetings, San Bernardino, CA, March 21-23, 1994, Abstracts with Programs, p. 78.

Oliver, H.W., and Mooney, W.D., 1992, Characterizing Yucca Mountain, Nevada, by geophysical methods (Extended Abstract): American Geophysical Union 1992 Fall Meeting Abstract Supplement, p. 490, Abs. T11A-13.

Oliver, H.W., Ponce, D.A., and Sikora, R.F., 1991, Major results of gravity and magnetic studies at Yucca Mountain, Nevada: Proceedings of the Second Annual International Conference on High Level Waste Management, Las Vegas, NV, April 28-May 3, 1991, American Nuclear Society, v. 1, p. 787-794.

Plouff, Donald, 1977, Preliminary documentation for a FORTRAN program to compute gravity terrain corrections based on topography digitized on a geographic grid: U.S. Geological Survey Open-File Report 77-535, 45 p. 
Ponce, D.A., and Oliver, H.W., 1981, Charleston Peak gravity calibration loop, Nevada: U.S. Geological Survey Open-File Report 81-985, 20 p.

Rasmussen, R., and Pedersen, L.B., 1979, End corrections in potential field modeling: Geophysical Prospecting, v. 27, no. 4, p. 749-760.

Rosenbaum, J.G., and Snyder, D.B., 1985, Preliminary interpretation of paleomagnetic and magnetic property data from drill holes USW G1, G2, GU-3, VH-I and surface localities in the vicinity of Yucca Mountain, Nye County, Nevada: U.S. Geological Survey Open-File Report 85-49, 73 p.

Sawyer, D.A., Fleck, R.J., Lanphere, M.A., Warren, R.G., Broxton, D.E., and Hudson, M.R., in press in 1994, Episodic caldera volcanism in the Miocene southwestern Nevada volcanic field: Revised stratigraphic framework, ${ }^{40} \mathrm{Ar} / 39 \mathrm{Ar}$ geochronology, and implications for magmatism and extension: Geological Society of America Bulletin, v. 106, p. $\mathbf{x x x}$.

Smith, Christian, and Ross, H.P., 1982, Interpretation of resistivity and induced polarization profiles with severe topographic effects, Yucca Mountain area, Nevada Test Site, Nevada: U.S. Geological Survey Open-File Report 82-182, 66 p.

Snyder, D.B., and Carr, W.J., 1984, Interpretation of gravity data in a complex volcanotectonic setting, southwestern Nevada: Joumal of Geophysical Research, v. 89, n. B12, p. 10193-10206. 
Spengler, R.W., Braun, C.A., Linden, R.M., Martin, L.G., Ross-Brown, D.M., and

Blackburn, R.L., 1993, Structural character of the Ghost Dance fault, Yucca Mountain, Nevada: High Level Radioactive Waste Management, Proceedings of the Fourth Annual International Conference, Las Vegas, Nevada, v. 1, p. 653-659.

Swick, C.A., 1942, Pendulum gravity measurements and isostatic reductions: U.S. Coast and Geodetic Survey Special Publication 232, 82 p.

U.S. Geological Survey, 1984, A summary of geologic studies through January 1, 1983, of the potential high-level radioactive waste repository site at Yucca Mountain, southern Nye County, Nevada: U.S. Geological Survey Open-File Report 84-792, 103 p.

U.S. National Bureau of Standards, 1977, The international system of units (SI): U.S. National Bureau of Standards Special Publication 330, 41 p. 
M98005247

||||||||||||||||||||||||||||||||||||||||||||-1

Report Number (14) US GS-OFR - $94-413-A$

Publ. Date (11) 1994

Sponsor Code (18) USGS, XF

UC Category (19) UC-000, DOE/ER

19980622070

DTIC QUALTIY INGPECTEDD 1

DOE 